\title{
Influence of the educational environment on students' managerial competence
}

\author{
Elena Razinkina ${ }^{1}$, Ludmila Pankova $^{2}$, Irina Trostinskaya ${ }^{3}$, Elena Pozdeeva ${ }^{3}$, Lidiya \\ Evseeva $^{3}$, and Anna Tanova ${ }^{3 *}$ \\ ${ }^{1}$ Peter the Great St. Petersburg Polytechnic University, Rector's Office, 195251 St.-Petersburg, Russia \\ ${ }^{2}$ Peter the Great St. Petersburg Polytechnic University, Basic Educational Programmes Department, \\ 195251 St.-Petersburg, Russia \\ ${ }^{3}$ Peter the Great St. Petersburg Polytechnic University, Advertising and Public Relations Department, \\ 195251 St.-Petersburg, Russia
}

\begin{abstract}
This paper considers university educational environment to be an important factor in the development of students' organizational and managerial competence. The authors discuss the approaches to the educational environment of the university, analyze its parameters and characteristics, and study the connection between the developmental educational environment and a high level of managerial competence attained by technical university graduates. The authors rely on the environmental approach which allows them to assess the impact of the educational environment on students' organizational and managerial competence taking into account the analysis of empirical data obtained by monitoring methods of sociological research. This method also made it possible to improve self-organization and self-management skills of students, and to achieve a high level of resilience both on the environmental and personal level.
\end{abstract}

\section{Introduction}

The creation of innovative clusters in the framework of the fourth industrial revolution generates a demand for new engineering personnel. The main requirement for the graduates in engineering today is that their level of competence must meet the professional requirements made by the state and employers due to the needs of technological development [1]. Digital technological environment creates new forms of interaction, new roles and functions of social institutions [2]. Graduates are not only required to have professional competencies, but also need to be ready to implement organizational and management activities, since these activities are necessary for further successful professional development and career growth.

The development of organizational and managerial competence of the students while mastering educational programs becomes possible only with the substantial support from the educational environment. The developmental educational environment contributes not

\footnotetext{
* Corresponding author: tanovaann@mail.ru, olgakalinina@,bk.ru
} 
only to the development of the competencies provided by educational programs, but also forms the skills of self-organization and self-discipline of the students. New educational technologies that emerged at the stage of digitalization require extensive distance learning and are aimed at a system of competencies, the core of which is independence, selfgovernment, self-control and the development of students' individual educational trajectories. The indicator of successful mastering educational programs as well as attaining competencies is the assessment of satisfaction with learning. The analysis of the competencies development is impossible without sociological surveys of students, which make it possible to identify difficulties and points of growth in the interaction of the university and the student on the basis of feedback.

For engineering professions, the new benchmark is the multivariance of educational trajectories that determine the entry into the profession [3]. Hence, it is important to develop a system of monitoring sociological research at a higher education institution and to monitor the effectiveness of the new social-pedagogical technologies.

Educational environment today is considered as a psychological and pedagogical system providing special conditions for individual development. According to Yasvin, educational environment is a system of conditions for individual development, also providing the necessary opportunities in the social and spatial-substantive environment [4]. Its main characteristic is the modality which is featured by the opportunities for the development of students' activity, their personal freedom and independence. These activities involve initiative, aspiration, perseverance and the ability to uphold and advocate their interests.

According to the research of Lesher and Khromov, students of technical universities are characterized by the dominant motivation for cognition, independence and critical thinking. Their main goal in education is to develop theoretical thinking and the ability to analyze and synthesize data. Students of technical universities are characterized by a high level of non-verbal intelligence, which implies the abilities for results-oriented activity, a high level of spatial, logical, synthetic and analytical thinking; they are characterized by a high level of concentration, high speed and accuracy of mental operations [5]. This fact emphasizes the importance of developmental educational environment that will allow technical universities to provide necessary educational conditions for the development of highly creative individuals.

According to the theory of opportunities of Gibson, the key element in the relationship between the environment and the subject (student) is the opportunity: the more actively and intensively the student uses the options provided by the environment, the more effective is its self-development [6].

The educational environment of a university is a set of conditions, types, forms of activity and social practices that provide education to a student and are aimed at developing a socially-oriented, purposeful, mobile and competitive personality of the future specialist $[7]$.

The educational environment that provides a high level of activity and the use of full potential of students acts as a developmental educational environment of the university. It is focused on the development of students' skills and brings them to a higher level. The developmental educational environment provides the systemic development of a student's personality, the growth of his intellectual, creative, psycho-physiological abilities, communication and self-development skills.

Among the indicators of the developmental educational environment [8] are the following:

- infrastructure (openness to new processes, efficient and intensively working research teams, development and improvement of educational programs;

- education and training (transdisciplinary approach, which assumes dialectical thinking and responsibility for research [9]); 
- reliance on "giftedness" (a student's readiness to realize his/her abilities "here and now", i.e., in the situation that allows for self-realization). Giftedness is a systemic concept that reveals readiness for experiments, self-organization and self-development, which contributes to the subject's going beyond the limits of homeostatic behavioral manifestations;

- dialogics (transcommunicativeness) of the educational system.

The effective influence of the developmental educational environment on the process of the student's self-development depends on the conditions that allow for the systematic development of the future specialist personality. The most significant parameters here are the following:

- psycho-physiological potential of the student, which is revealed in their adaptability, efficiency, flexibility, independence, mobility and discipline;

- educational potential which implies the professional values, professional competence and the ability for self-education;

- qualification potential which implies entrepreneurial skills, competitiveness, critical thinking;

- creativity which implies creativity, social activity and organizational qualities;

- communicative potential which supports the intention to work in a team, openness, empathy, tolerance and willingness to cooperate;

- moral potential which is based on responsibility, honesty, culture values, civic stance and patriotism.

The developmental educational environment of the Polytechnic University ensures the freedom of professional choice and worldview of a student, the development of a competitive specialist, who is adaptable to the high dynamism of the modern market.

There is also an emotional component in the field of the developmental educational environment. It is directly associated with the emotions reflecting the subject's inner experiences in relation to himself and the world around him. The emotional component in the educational environment is responsible for adaptive and mobilizing functions. There is a direct relationship between the student's emotional state and the results of his educational activities, since the positive emotional state motivates his learning [10]. An integral part of the developmental educational environment today is the cognitive component which implies a set of cognitive processes. Being responsible for the information and cognitive function, this component today comes on line, as it is associated with the development of new intellectual technologies introduced in "smart universities", which indicates the university's innovativeness and determines its prospects. It is also important to take into account that in the case of a high level of students' independence, the educational environment will contribute to the professional and personal growth of students if it corresponds to the sociocultural vector of the development of society today [11].

The influence of factors of the educational environment is ambiguous, and it reflects a positive and negative impact. Among the factors that adversely affect the satisfaction of students with the university educational environment there are physiological, psychological, spatial, transport and economic factors [12].

One of the important characteristics of the educational environment of a university is comfort. The comfortable environment of the university is a complex dynamic system capable of influencing the development of the intellectual culture of students and capable of changing in accordance with the needs of society. It is associated with the parameter of the personality-stimulating environment, which must meet the following requirements [13]:

- aesthetic appeal of the environment (architecture of buildings and structures, modern interior design, personalized lecture halls, modern computer and information teaching aids, facilities for scientific and laboratory research); 
- the problematic and research character of the content of education, its focus on professional training of future university graduates;

- redundancy and variability of the elements of the educational environment that can meet the professional and personal needs of the students and teachers and ensure the choice of individual educational trajectories;

- high level of psychological and pedagogical culture of communication and interaction of subjects of the educational process, its positive content;

- functionality and ergonomics of the educational environment (variety and multiplicity of the functional elements of the environment, convenience and safety of their use in the professional and personal development).

The orientation of higher education to the demands of the market determines the need for the formation of organizational and managerial competence in the framework of an integrated model of professional activity. The implementation of a competence-based approach in higher education is aimed to provide the training of highly qualified specialists with professional competencies and required personal qualities that enable them to use their technical knowledge, skills and abilities together with the organizational, managerial and communication skills.

By organizational and managerial competence of technical university graduates we imply a variety of emotional, intellectual, communicative, personal and organizational competencies that will ensure the capability of the future engineer to solve organizational and managerial tasks that meet the requirements of the production process, modern sociocultural norms and systems of social axiological orientations in the conditions of market economy. The structure of organizational and managerial competence, being a controversial issue, is rather complex [14-16].

The structure of managerial competence of technical university students presented by Goncharov [17] is most complete and reflects the current trends in the development of the educational model. Goncharov highlights the following components in the structure of managerial competence: motivation-and-value, cognitive, activity, reflexive and emotionalvolitional. This correlates with the integrated implementation of students training in three main areas:

- theoretical and methodological (due to the introduction of a system of special educational courses);

- value-oriented (due to the internship with the focus on the development of organizational and managerial competence, students' research and individual work, graduate engineering design);

- professional and personal (extracurricular educational work).

Advanced practice of developing the organizational and managerial competence of the technical university students facilitated by the developmental educational environment makes it possible for the students to achieve learning satisfaction, reinforces the competitiveness of the university and raises the quality of educational services.

\section{Materials and Methods}

Satisfaction with the quality of engineering education is the prerequisite of the efficient engineering training and it is focused on developing the ability of the students to create "human-sized" systems and acquire the necessary skills for the "organizational creativity" mode. The creative ability to tackle complex tasks extends the managerial potential of a specialist, and the creative approach sets up multiple opportunities that are needed for work in the conditions of uncertainty [18]. Satisfaction with learning reflects the connection between the degree of realization of a student's social expectations and the effectiveness of the higher educational institution [19-20]. The educational situation today is characterized 
by the ambiguity, as students are willing to develop business skills alone, while employers need specialists with different competencies and attitudes. This generates a demand request for "transprofessionals", with a universal set of the competencies developed [21].

The authors used the environmental approach that became popular at the turn of the twenty-first century. The environmental approach is considered as a leading factor in the development of education. Along with the communicative-oriented, ecologicalpsychological, pedagogical and anthropological-psychological approaches, environmental approach has its advantages: it considers education as an open, self-organizing, non-linear, dynamic system. Within the framework of this approach, the effectiveness of training depends on the degree of consistency, interaction, collaboration and self-development of the students in the educational environment. Application of the environmental approach in the training of future engineers can be a key factor in achieving openness, dynamism and competitiveness of universities.

Environmental factors in the formation of managerial competence are noted in publications where the processes of influence of sociocultural [22], sociotechnical, geopolitical [23], urban and others environments are identified.

The current situation related to the development by universities of new tools for the individualization of education requires an expansion of research and monitoring methods, which allows us to identify problems and establish the dynamics of change. Sociological monitoring allows you to analyze the level of student satisfaction with learning, reflects the level of their competence as well as organizational and management skills necessary for successful activity in the market. The sociological surveys of satisfaction with learning in technical universities show that satisfaction is viewed as a comprehensive assessment, with the motivational component at its core, the positive parameters of which clearly correlate with satisfaction indicators [24].

\section{Results}

The following statements were formulated as hypotheses for the study:

- An indicator of attitudes towards the educational environment of the university is student's satisfaction with learning, as it reflects the adequacy of the conditions and opportunities provided by the university in response to the expectations and demands of students. Satisfaction with learning is monitored through monitoring surveys aimed at providing a comprehensive assessment of satisfaction with the quality of educational programs and the conditions of training.

- Students' readiness for entrepreneurial and innovative activities demonstrates a growing educational environment that ensures graduate readiness for dynamic market conditions and risk-related activities.

- The level of the student's organizational and managerial competence reflects his skills in using the electronic educational environment of the university and distance learning technologies.

In order to test these hypotheses a number of studies were conducted at St. Petersburg Polytechnic University. In June 2018, the Center for Sociological Research at the Department of Advertising and Public Relations of the SPbPU Institute of Humanities conducted a sociological survey of students as part of monitoring satisfaction with the quality of educational programs (the sample group of students numbered 3675 with a total number of 19816 students). The survey results reflected the attitude of students to the education provided by the university and to the educational environment with its opportunities for different activities and the development of competences.

The survey results showed a fairly high level of student satisfaction with educational programs - 67\%, and the interrelation of indicators that remain (compared to 2017) 
consistently high (see Table 1), with an exception of the indicator of the future professional activity, which has slightly decreased compared to previous year.

Table 1. Indicators of student satisfaction with learning at SPbPU.

\begin{tabular}{|l|c|}
\hline \multicolumn{1}{|c|}{ Indicators } & $\mathbf{\%}$ \\
\hline Overall learning satisfaction & $67 \%$ \\
\hline Training meets their expectations & $66 \%$ \\
\hline Going to work in the field of their major after graduation & $66 \%$ \\
\hline Know where they will work & $48 \%$ \\
\hline
\end{tabular}

According to the survey, the SPbPU educational environment provides favorable conditions not only for educational, but also for extracurricular activities of the students. However, the opportunities to develop in their free time, using the resources of the university, are not fully realized, and the reserves of students' activity are not fully tapped. Thus, the activity of the students associated with their participation in various events held at the university, is revealed by the following data (see Table 2):

Table 2. Participation of the students in extracurricular activities at SPbPU.

\begin{tabular}{|l|c|c|}
\hline \multicolumn{1}{|c|}{ Type of event } & Did not participate & $\begin{array}{c}\text { Participated } \\
\text { ("rarely" + "often" } \\
\text { summed up) }\end{array}$ \\
\hline Scientific & $54 \%$ & $46 \%$ \\
\hline Student meetings & $64 \%$ & $36 \%$ \\
\hline Cultural & $50 \%$ & $50 \%$ \\
\hline Sports & $65 \%$ & $36 \%$ \\
\hline Clubs and interests groups & $74 \%$ & $26 \%$ \\
\hline
\end{tabular}

Thus, there is a fairly significant share of untapped resources for the students' initiative in the scientific, creative field and in the field of self-development.

In 2018, a survey was conducted using an online survey method (sample group of 108 people) within the topic "Readiness of engineering students for innovation and business", which reflected the entrepreneurial spirit of polytechnics and their interest in innovative activity. Students showed a positive attitude towards entrepreneurs on the whole $(65 \%)$, although the share of those who already have their own business experience is small - only $13 \%$ ( $6 \%$ of students identified themselves as entrepreneurs).

At the same time, a positive attitude of students towards doing business is correlated with the presence of entrepreneurs among their acquaintances and relatives: $73 \%$ of respondents said that they have entrepreneurs among their friends; $30 \%$ of respondents said that there are entrepreneurs in their families. Half of the students surveyed are planning to organize / continue their business activities in the near future, a third of the respondents $(30 \%)$ have not yet decided, and $20 \%$ of the respondents have negative attitude to business.

The important point is that among the necessary qualities for an entrepreneur students identified those that are developed in a university environment (see Table 3):

Table 3. Qualities important for the entrepreneur

\begin{tabular}{|c|c|c|c|}
\hline List of qualities & $\begin{array}{c}\text { Important qualities } \\
\text { for the } \\
\text { entrepreneur }\end{array}$ & $\begin{array}{c}\text { Students } \\
\text { qualities }\end{array}$ & $\begin{array}{c}\text { Qualities } \\
\text { developed at the } \\
\text { university }\end{array}$ \\
\hline
\end{tabular}




\begin{tabular}{|l|c|c|c|}
\hline $\begin{array}{l}\text { Diligence and } \\
\text { purposefulness }\end{array}$ & $88 \%$ & $62 \%$ & $53 \%$ \\
\hline $\begin{array}{l}\text { Education, } \\
\text { professionalism }\end{array}$ & $60,5 \%$ & $39 \%$ & - \\
\hline Creativity & $71,5 \%$ & $36 \%$ & $19 \%$ \\
\hline Interpersonal skills & $87 \%$ & $46 \%$ & $40 \%$ \\
\hline $\begin{array}{l}\text { Willingness to take } \\
\text { risks, adventurism }\end{array}$ & $69 \%$ & $38 \%$ & $33 \%$ \\
\hline $\begin{array}{l}\text { Leadership qualities } \\
\text { and activity }\end{array}$ & $93 \%$ & $43 \%$ & $31 \%$ \\
\hline Foresight & $80 \%$ & $26 \%$ & $32 \%$ \\
\hline $\begin{array}{l}\text { Law-obedience, } \\
\text { honesty }\end{array}$ & $29 \%$ & $37 \%$ & $15 \%$ \\
\hline Ingenuity & $77 \%$ & $41 \%$ & $50 \%$ \\
\hline Frugality, thrift & $74 \%$ & $38 \%$ & - \\
\hline $\begin{array}{l}\text { Ability to work with } \\
\text { information }\end{array}$ & - & - & $69 \%$ \\
\hline Organizational skills & - & $7 \%$ & $30 \%$ \\
\hline All of the above & - & - & - \\
\hline None & & & \\
\hline
\end{tabular}

The least important qualities for the entrepreneur, according to the students, were lawobedience and honesty (29\%), while the most important ones are the following: leadership qualities and activity (93\%), diligence and purposefulness (88\%), interpersonal skills $(87 \%)$. The willingness to take risks is considered important by $69 \%$ of respondents. The role of the university is revealed in the development of such qualities as: dedication and hard work (53\%), sociability (40\%) and ability to work with information $(69 \%)$. Unexpectedly, a small number of responses (19\%) were given to creativity, which poses serious challenges for the future educational environment. According to students, the university ought to pay more attention to this issue, providing conditions for the development of organizational and leadership skills and creative approaches. This can become possible with the involvement of the students in the work of innovative and research organizations affiliated with SPbPU. Most students are informed about these structures but do not actively participate in their activities.

Social activities of the students within the framework of the educational environment require the development of organizational and managerial competences and imply good organization of their time, discipline, self-control and self-analysis. The development of these competencies is facilitated by distance learning programs of the university.

In November - December 2018 a sociological survey was conducted at SPbPU among the students of the 1 st and 2 nd year of study to analyze their attitudes towards distance learning (the sample group numbered 501 students).

The following answers were given to the question "What is your attitude to studying a number of disciplines online?" (Figure 1). 


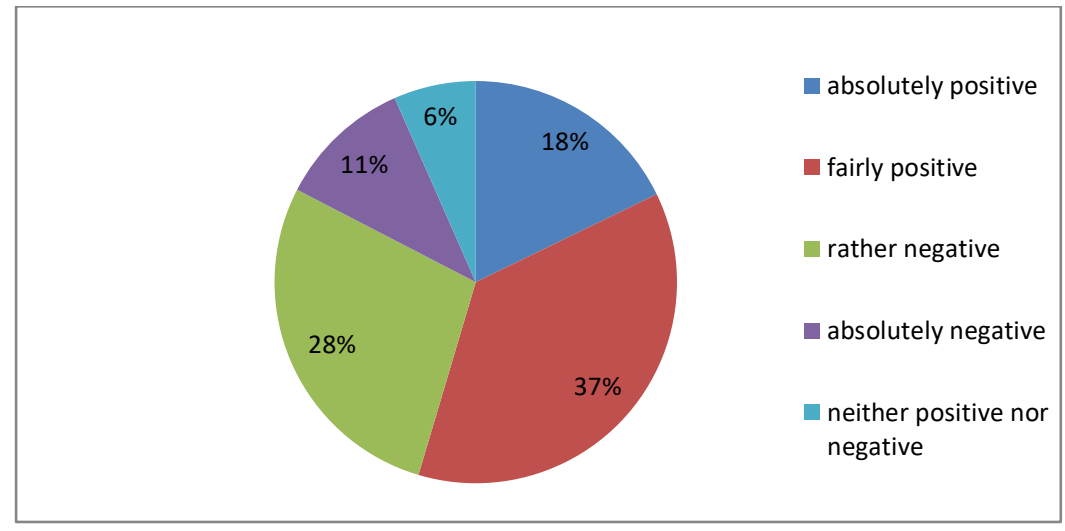

Fig.1. What is your attitude to studying a number of disciplines online?

When answering the question about their preferred form of education - traditional, distance or a combination of them, the majority of respondents preferred a combination of traditional and distance learning (54\%), 37\% chose traditional one and 3\% chose distance learning.

The most significant shortcomings of distance learning mentioned were the following: the lack of operational advice from the teacher $(58 \%)$, difficulty in meeting deadlines $(52 \%)$, the lack of live communication with the teacher $(46 \%)$, technical problems when working on the Internet (44\%), difficulties with learning motivation $(42 \%)$, difficulties in performing tasks within the online courses (42\%), negative impact on eyesight due to the constant work on the computer (31\%).

When asked the question of whether distance learning contributes to the development of students' skills for self-mastering educational material, students answered in the following way (Figure 2):

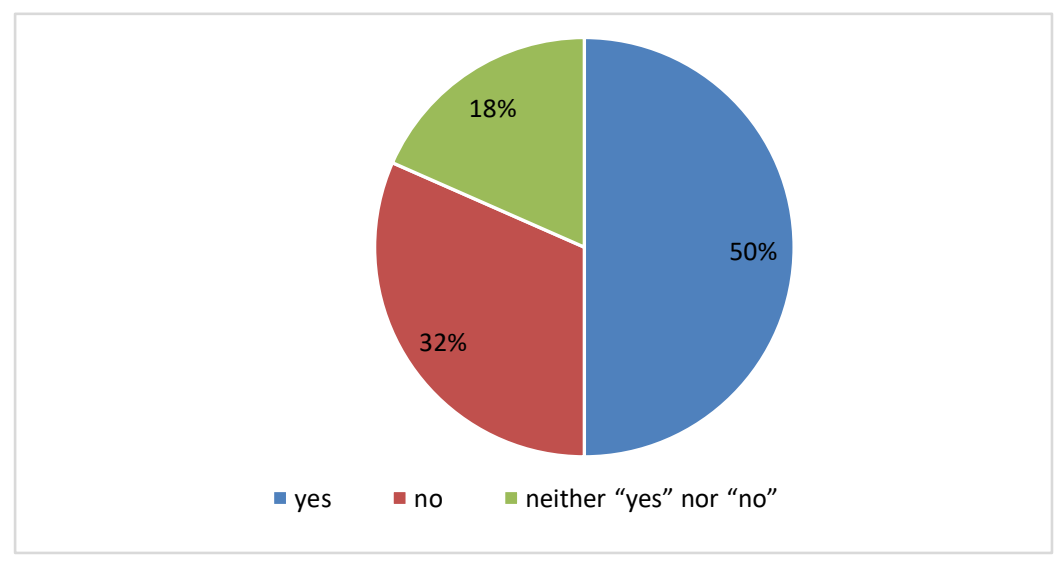

Fig.2. Do you think that distance learning contributes to the development of students' skills for selfmastering educational material?

The overwhelming choice of the combination of educational forms (distance and traditional learning) is due to the fact that it allows them to eliminate such shortcomings of online learning as "difficulties with learning motivation" (42\%), "difficulties with meeting deadlines" $(52 \%)$, since in face-to-face communication the teacher can remind the students of the need to complete the task on the online portal. 
The survey data indicate a lack of students' organizational and managerial competence. The importance of time management is recognized by the students, but so far they have not really succeeded in it.

\section{Discussion}

Further discussion of the issue dedicated to the improvement of the university educational environment may be associated with such feature as resilience. The resilience of a system is understood as the ability to prevent significant difficulties, to experience difficulties with minimal losses and minimal systemic and balance violations. It is possible to develop this feature of the educational environment by improving the management of the educational process as well as system management of internal and external factors. The internal factors are the following: a creative approach, models of positive interactions, the conventionality of the value system, a positive vision of the future, flexibility in design and decision-making. External factors include the feeling of security, the support provided to students in an educational organization, high expectations, the establishment of clear rules and boundaries that are recognized by all; the important role is given to the atmosphere of trust and respect.

The resilience of the environment is also provided by the development of students' meta-competencies. The students' meta-competencies that are in demand today are based on endurance, resilience, self-regulation and empathy. Resilience as an element of student's meta-competencies is understood as the ability to "withstand the blow" in case of his failures, under the threats and challenges. Resilience is formed as the ability of an individual to protect his integrity when he is under strong pressure, the ability to survive and keep developing in difficult conditions, which also implies the ability to plan his life on the basis of conscious goal-setting [25].

The conducted research allows us to quickly monitor the dynamics of changes in the development of the organizational and managerial competence of the students. With the help of sociological research, you can monitor the influence of the educational environment on the development of activities, independence, creativity of the students, their involvement in the work in the electronic educational environment, and check their level of time management and planning skills. For the personal fulfillment of the students it is particularly important to expand the practice of their participation in goal-setting and development of their own educational trajectories, to engage them in university projects and independent scientific and creative activities as well as cultural, sports and leisure activities.

\section{Conclusions}

In the course of the study, the hypotheses put forward earlier were tested. The results obtained confirm the hypothesis of student satisfaction with learning as an indicator of their attitude to the educational environment. A high degree of students' satisfaction with university studies was revealed, which justifies the use of the environmental approach and indicates the importance of interaction between the educational environment and students that results in synergistic effects. This study also confirmed the hypotheses about the role of the educational environment in ensuring students' readiness for entrepreneurial and innovative activities and about the influence of the educational environment of the university on the development of students' competence, which allows them to use distance learning technologies in learning process. All this proves the key influence of the educational environment of the university on the development of organizational and managerial competence of students. 
Based on the analysis of the data obtained, conclusions are made about the possibilities of improving the educational environment of the university to ensure optimal conditions for the development of students' organizational and managerial competence.

\section{References}

1 E. Pozdeeva, V. Fetisov, A. Boronoev, Sociological Studies, 10, 157 - 158 (2018) doi: $10.31857 /$ S013216250002168-7

2 O. Shipunova, I. Berezovskaya, L. Mureyko, V. Evseev, L. Evseeva, Revista ESPACIOS, $\quad \mathbf{3 9 ( 4 0 ) ,} 15$ doi:http://www.revistaespacios.com/a18v39n40/18394015.html

3 A. Danilov, M. Gitman, V. Stolbov, E. Gitman, Higher education in Russia, 27(3), 5 - 15 (2018)

4 V. Yasvin, Proceedings of the Saratov University, 2, 33 - 37 (2012) https://cyberleninka.ru/article/n/otsenka-studentami-universitetskoy-sredy-na-osnovemetoda-vektornogo-modelirovaniya, (last accessed 19.03.2019)

5 O. Lesher, P. Khromov, Modern problems of science and education, 1 (2017) http://science-education.ru/ru/article/view?id=26125, (last accessed 19.01.2019)

6 G. Gibson, An Ecological Approach to Visual Perception (Moscow, Progress, 1988)

7 L. Berezhnova, V. Bogoslovsky, Izvestia: Herzen University Journal of Humanities \& Science (5) 12, 109 -122 (2005) https://cyberleninka.ru/article/n/soprovozhdenie-vobrazovanii-kak-tehnologiya-razresheniya-problem-razvitiya, last accessed 19.01.2019

8 V. Klochko, O. Krasnoradtseva, Learning Psychology, 4, 4 - 13 (2013)

9 G. Berger, Interdisciplinary: Problems of Teaching and Research in Universities (Paris, OECD, 1972)

10 E. Kiseleva, Proceedings of the Kostroma State University. Series: Pedagogy.

Psychology. Sociokinetics, 4 (2016) https://cyberleninka.ru/article/n/ekspertnayaotsenka-mezhlichnostnyh-otnosheniy-kak-resursa-emotsionalnoy-bezopasnostiobrazovatelnoy-sredy, (last accessed 19.01.2019)

11 E. Lesher, E. Arishina, Development of the axiological potential of university students in the process of vocational training: the praxeological aspect (Magnitogorsk, MSTU, 2009)

12 G. Avdienko, Psycho-pedagogics in law Enforcement agencies, 1 (2018) https://cyberleninka.ru/article/n/povyshenie-effektivnosti-obrazovatelnogo-protsessapozitivnym-vliyaniem-na-sotsialno-psihologicheskuyu-komfortnost, (last accessed: 01.04.2019)

13 V. Novikov, Psychological Science and Education, 1, 1 - 10 (2012) http://psyedu.ru/, last accessed 19.01.2019

14 N. Agladina, Modern problems of science and education, 6, 97 - 101 (2018)

15 D. Kachalov, World of Science, 5(2) (2017) http://mir-nauki.com/PDF/24PDMN217.pdf, (last accessed 18.01.2019)

16 A. Akhterov, A. Shastina, O. Lezina, Automation and control in technical systems, 4.2, (2013) doi:10.12731/2306-1561-2013-4-28 
17 P. Goncharov, Pedagogical journal, 1-2, 124 - 132 (2013)

18 A. Shamsi, Foresight and STI Governance, 11(4), 44 - 51 (2017) doi: 10.17323/2500-2597.2017.4.44.51

19 A. Tanova, L. Evseeva, E. Pozdeeva, I. Trostinskaya, St. Petersburg State Polytechnical University Journal. Humanities and Social Sciences, 9(1), 90 - 101 (2018) doi:10.18721/JHSS.9110

20 E. Razinkina, L. Pankova, I. Trostinskaya, E. Pozdeeva, L. Evseeva and A. Tanova, E3S Web of Conferences, 33, 8 (2018) doi.org/10.1051/e3sconf/20183303043

21 G. Perkin, The Rise of Professional Society: Britain since 1880 (Routledge, London, 2002)

22 O. Shipunova, I. Berezovskaya, International Journal of Civil Engineering And Technology (IJCIET), 9(10), $2020 \quad-\quad 2028 \quad$ (2018) doi:http://www.iaeme.com/IJCIET/issues.asp?JType=IJCIET\&VType=9\&IType $=10$

23 A. Matveevskaya, S. Pogodin, Vestnik of Saint Petersburg University. Philosophy and Conflict Studies, 33(1), 115-118 (2017) doi:10.21638/11701/spbu17.2017.112

24 A. Andrienko, Journal of Siberian Medical Sciences, 1 (2007) https://cyberleninka.ru/article/n/ udovletvorennost-pervokursnikov-protsessomobucheniya-v-vuze, (last accessed 01.18.2019)

25 A. Muraveva, O. Oleynikova, Kazan Pedagogical Journal, 2(121) (2017) https://cyberleninka.ru/article/n/nedootsenennaya-kompetentsiya-ili-pedagogicheskieaspekty-formirovaniya-rezilientnosti, (last accessed 01.17.2019) 